\title{
CESTA ZPÁTKY - DOMOV NA POHLEDNICÍCH 1. SVĚTOVÉ VÁLKY
}

\author{
KAMIL BEER \\ Fakulta humanitních studií Univerzity Karlovy \\ Kamil.Beer@seznam.cz
}

\begin{abstract}
The Road Back - Depictions of Home on First World War postcards

Postcards and posters were the primary medium of visual communication during the World War I. Propaganda used them to incite patriotism in the reader, using various images and visual motives. One of them was the portrayal of home. This article explores how was home depicted on the Central Powers' and Entente's posters and postcards and if there were any differences and/or similarities between them.

Keywords: World War I - propaganda - postcards - portayal of home
\end{abstract}

Za 1. světové války bylo mobilizováno 65 milionů vojáků a každý z nich měl domov, ze kterého byl vytržen. Bojovali z povinnosti i ze strachu o blízké, někteří také za svoji vlast nebo za panovníka. Toto vše mohlo znamenat domov. Vykořenění vojáci s domovem udržovali spojení, bylo pro ně nutné si uchovat jeho obraz a být s ním alespoň v myšlenkách. Rozdávání dopisủ byl jediný světlý bod celého dne. Často se ke spojení mezi vojáky na frontě a rodinou $\mathrm{v}$ zázemí používaly i pohlednice.

A právě ty byly v dobách první světové války vedle zmíněných dopisů nejčastější médium komunikace. Bylo možné skrz ně vyjádřit řadu pocitů, protože vzkaz posilovala i obrazová složka pohlednice, nabitá emocemi. Tyto ilustrace mohly být humorné, nostalgické, milující i nenávistné, a tak se zamlouvaly vkusu různých pisatelů i čtenářů. Použití pohlednic „nahrávala“ i nízká nákladovost výroby, což podporovalo masové širrení patriotických myšlenek s minimálním zásahem státu. Vzkazy podléhaly přísné cenzuře, korespondent např́ílad nesměl udávat místo nasazení nebo že se mu nedaří. A ačkoli vojáci měli často na výběr pouze předtištěné pohlednice se vzkazy (na rozdíl od civilistů), běžné pohledy snadno koupili ve městech poblíž frontě.

Propaganda měla za cíl podpořit (nebo, u neprátel, podlomit) morálku ve stavu totální války, ve které se do té doby Evropa neocitla. Proto potřebovala nástroje, které by obyvatelstvo nadchly pro konflikt a nepř́itele zabarvily do nejhorších barev. O úspěšnosti této propagandy mohou být důkazem např́íklad i tvrdé podmínky a vysoké reparace, předložené Německu v letech 1919-1920 na Pařižské mírové konferenci. Popularity pohlednic tedy propaganda hned využila - obrázkové vzkazy z fronty se posílaly bezplatně a obsahovaly různé emotivní ilustrace, které připomínaly právě i domov. Ten byl znázorňován i na plakátech v zázemí. 
Studie se zabývá tím, co na pohlednicích domov vlastně znamená, jaké obrazy pro něj volí centrální mocnosti a státy Dohody, zda se tato vyobrazení nějak liší nebo jestli se shodují (a v čem). Práce se soustředí primárně na pohlednice, ale občas uvede př́klad znázornění domova i na propagandistických plakátech. Zdroji pro studii byly aukční domy a archivy, kde byly pohlednice uchovávány, např́klad britské Imperial War Museum, americké Library of Congress nebo rakouské Österreichische Staatsarchiv. Výzkum proběhl na vzorku menších stovek dobových pohlednic a plakátů.

\section{Rakousko-Uhersko a Německo}

Právě ve Vídni vznikla v roce 1871 první pohlednice, kde obrázek zastupoval funkci suvenýru, něčeho se samostatnou hodnotou. ${ }^{1}$ V Německu byly pohlednice uvedeny krátce před začátkem prusko-francouzské války let 1870-1871. Pohledy se staly velice populárními - v roce 1913 bylo údajně odesláno 30 pohlednic „na osobu“.2 Pouze němečtí vojáci odhadem odeslali až pět a půl milionu dopisů denně; celkově se odhaduje, že během války bylo ze zázemí odesláno 30 miliard dopisů a balíčků, z toho 10 miliard pohlednic. ${ }^{3}$

Rakouské pohlednice nám často ukazují domov, reprezentovaný vladařem: např́klad na jedné pohlednici si jako památku na domov voják v zákopu vyvěsil kresbu císaře Františka Josefa I., na jiné pohlednici se císař nachází ve shluku osob - nejen mezi vojáky, ale i mezi ženami a dětmi - součástmi domova. Na další pohlednici se vedle vladaře nachází Pražský hrad a Karlštejn.

Když se podíváme na pohlednice německé, toto znázorňování Viléma II. nevidíme bývá sice na pohlednicích zobrazován, ale bud'v uniformě sám, nebo mezi vojáky, jen zřídka s civilisty. Podařilo se nalézt jedinou pohlednici, kde je císař po boku dělníků a námořníků, kteři jásají - což také znázorňuje široce rozšířený mýtus, že při vstupu do války všechny společenské vrstvy na všech místech podporovaly vstup do konfliktu. Na jiné pohlednici je Vilém II. vyobrazen tak, že ačkoli ve spodní části pohlednice voják píše domů o tom, jak „jeho paže patří císaři, jeho srdce vlasti“, vpravo nahoře vidíme císaře, dohlížejícího na něj. Jindy je zobrazen jako poslední myšlenka vojáka, který umírá se slovy „Mein Kaiser!“.

Na německých pohlednicích je domovem také velmi často vlast. Jednou vidíme vedle vojáka text písně „die wacht am Rhein“ o vlasti, kterou stráží stráž na Rýně. Během války vznikaly i další básně a písně, opěvující „otčinu“, stejně jako plakáty a hnutí, kde nechybělo v názvu slovo „Heimat“ (domovina), nebo „Vaterland“ (otčina či vlast). Některá z těchto hnutí se dostala taktéž na plakáty - existovaly sbírky „Vaterlandsdank“, na nichž se shromaždovaly po velkou část války zlaté a stř́íbrné předměty. Dárce za to obdržel nerezový prsten s nápisem „Vaterlandsdank“. Tyto sbírky se objevují i na propagandistických plakátech. Z abstraktního termínu domovina vzniká něco jako oživlá bytost, které lze poděkovat. Mezi všemi těmito pojmy jako „Heimat“ a „Vaterland“ bylo zásadní

\footnotetext{
Staff Frank, The picture postcard \& its origins, Cambridge 1979.

2 Rainer Traub - Christoph Gunkel, Propaganda-Postkarten im Ersten Weltkrieg. Singend in den Tod, Spiegel Online, https://www.spiegel.de/geschichte/bildpostkarten-im-ersten-weltkrieg-a-1026685 .html, vyhledáno 16. 1.2021.

3 Ibidem.
} 
zdůraznit i ohrožení domova. Plakáty hovoří o záboru levého břehu Rýna Francií a další zase o úmyslu Anglie rozbombardovat Porýní.

Sérii abstraktních, ale přesto vážných obrazů na pohlednicích doplňují náboženská zobrazení, at už se jedná o anděly, nebo obrazy Krista a jiných figur, což dává obrazu ještě další rozměr, kterým pohled promlouvá na diváka.

U trojspolku existují i pohlednice s mnohem více každodenní a apolitickou částí domova, kterou jsou ti nejbližší. Vojákův di̊m, žena, děti, matka. Nejčastěji je na pohlednicích manželka, mnohdy se opakuje spojení „Na dovolené - voják se s ženou loučí nebo žena vzpomíná. Takové obrazy měly vyvolat představu toho, co vojáka čeká a podpořit ho.

Na již zmíněné německé pohlednici se také nachází voják loučící se se ženou, ovšem pod př́sným dohledem císaře $\mathrm{v}$ horní části pohlednice $\mathrm{v}$ jakési nadpřirozené podobě. Je zde hned několik výrazů domova: žena, císař, vlast. Pro vojáka tak bylo snadné se ztotožnit alespoň s něčím, zvlášt když byl sám na pohlednici vyobrazen tak, jaký je, bez heroických atributů.

Na jiných pohlednicích byla v horní části pohlednice (kde byl na našem prŕkladu císař) často vyobrazena i žena. Nacházela se v jakési vizi, např́íklad když si ve spodní části ilustrace voják četl dopisy, v horní části mu je žena psala. Toto byl motiv známý z náboženských vyobrazení a je více popsán v následující části.

Jindy se na pohledech objevuje matka či novorozenec. Motiv dětí je v tomto období využívaný všemi stranami. U Německa si můžeme povšimnout pohlednice, kde malý chlapec v uniformě vzkazuje, že „my nehladovíme“. Zpráva o nehladovění působí nepatřičně s ohledem na to, $\mathrm{v}$ jaké hospodářské situaci bylo Německo $\mathrm{v}$ druhé polovině války, kdy docházelo k masivnímu snížení zemědělské produkce a nedostatku potravin. ${ }^{4}$ Nicméně takové pohlednice mohly adresáty z řad vojáků ubezpečit, že se jejich rodině dobře daří. Jiné pohledy s dětmi už tolik neporazitelnost nevyjadřovaly, například kde se dítě modlí za svého otce.

\section{Británie a Francie}

Britský historik George Macaulay Trevelyan tvrdí, že na začátku války byl pohled Británie na válku spíše galantní a idealistický a inscenoval Brity jako „zachránce Evropy“. Stěží někdo myslel na válečnou kořist či reparace. Ovšem vlivem různých válečných zločinů (at už pravdivých, či nepravdivých) a nutnosti udržet podporu válce v zázemí i na frontě byla vybičována nenávist k nepříteli tak, že „Hun byl brán jako nelidský, a všichni, kdo jej viděli jako lidského, byli neprátelé (...) Prodloužení takové války na čtyři roky zničilo možnost rozumného míru, protože jeho podmínky bylo třeba dohodnout dřive, než došlo k ochlazení zjitřených emocí..."5

$\mathrm{V}$ případě Británie, možná vlivem snah oficiálního propagandistického centra „Wellington House“, kde pracovali pro válečné snahy přední umělci, se potenciál pohlednic stal okamžitě zřejmým - a dokonce byly dostupné ještě dříve, než britský expediční sbor

4 Více napr. Roger Chickering, Imperial Germany and the Great War, 1914-1918, Cambridge 1998, s. 141-146.

5 George Macaulay Trevelyan, British History in the Nineteenth Century and after 1782-1919, City of Westminster 1979, s. 457. 
dorazil do Francie. Na britských pohlednicích vidíme domov například jako práci $v z a ́-$ zemí - zaměstnanou mladou ženu a starce. Na obrázku je explicitně řečeno „18 and 80“, což dále poukazuje na stav totální války. Ženy i staří pracují a voják se jimi nesmí nechat zahanbit. Tento emoční tlak na zostuzení vyvíjela britská propaganda i v jiných oblastech, např́iklad skrz hnutí „bílého pírka“, které „vydíralo“ muže, kteří dobrovolně nenastoupili do armády.

Plakáty a pohlednice států Dohody často zobrazují mnohem světštější motivy, nežli je císař nebo vlast. U Francie dominuje plakátům i pohlednicím častý motiv návratu domů, též mezi ženy, děti, do idylické vsi. Světská je také pomoc z domova například ve formě balíčků zásob, které vojáci dostávali z fronty. Ve spojení s vlasteneckým a skoro až dětským stylem kresby Image d'Epinal vidíme na různých pohlednicích spojení s domovem formou proudu darů na frontu - oblečení, tabáku, masa i dokonce srdíček. Na německých plakátech a pohlednicích motiv dárků také vidíme, byt realističtěji znázorněný, zejména na Vánoce.

Ve francouzské propagandě se často opakuje specifická kompozice: zatímco v dolní části obrazu se nachází realistická scéna, v horní části je něco nadpřirozeného či vzdáleného. Mưže to být např́iklad žena vzpomínající na vojáka. Tato kompozice připomíná náboženská zjevení a vize z předválečného světa. Na pohlednici mohou představovat vzpomínku vojáka na domov nebo válečnou scénu na vrchu a domovskou na spodku. Nebo zemi a nebe. Je tedy zřejmé, že takto složené obrazy navozovaly pocit spojení domova a vojáků. V sérii pohlednic s realisticky ztvárněnými aktéry se tento motiv často opakuje, např́íklad se vzpomínajícími ženami.

Některé tyto pohlednice jsou skutečně kontrastní: již jsme si zmínili tu, kde nahlíží seshora na německého vojáka, loučícího se s ženou, císař. Francouzských pohlednic, které by zobrazovaly významné osobnosti, je málo, ale přece jsou: na jedné pohlednici jsou dokonce motivy tři, generál Joffre, vojáci v boji a žena. Lépe kontrast ale ilustrujeme na dvojici pohlednic, kde se nachází žena a duch vojáka (viz přiložené obrázky). Zatímco německá pohlednice je temná a vážná, s popisem „nur wer die sehnsucht kennt weiss was ich leide“ (v překladu „Pouze ti, kteří znají stesk, vědí, čím trpím“), francouzská vyznívá mnohem pozitivněji.

Některé rakousko-uherské pohlednice, které využívají tuto kompozici, jasně sdělují, co je domov: domovem je modlící se císař v dolní části scény, který myslí na své vojáky v části horní (ve vizi). Jiné zůstávají zcela na bojišti: habsburský voják místo představy domova myslí na vítězství - ženu a děti nahradil poražený protivník... Pohlednice je nadepsaná jasně: „Vision“.

Zejména u trojspolku domov symbolizují děti, které myslí na svého otce, posílají mu vzpomínky a objetí. Pohlednic s dětmi byl široký výběr podle toho, kolik jich voják měl, jak staré, a zda to byli chlapci nebo dívky. Nebo se domov rovnal vesnici či zemédělství na jednom z plakátů voják v dolní části sní o idylické vesnici v části horní. Na jiném plakátě s vizí vojáci myslí na sběračky na polích. Děti a ženy jsou na těchto francouzských plakátech občas oděny v alsaských čepcích; v této souvislosti může domov vojáka symbolizovat i Alsasko-Lotrinsko, anektované Německem po francouzsko-pruské válce let 1870-1871, a možnost ho od císařství vybojovat zpět. 


\section{Závěr}

Po průzkumu pohlednic a plakátů zjištujeme, že to, čemu říkaly znepřátelené strany „domov“, se prŕliš̌ nelišilo, a to i přes řadu obrazů vladařu (které převažují u ústředních mocností) a „světských“ radostí (převažujících u států Dohody), což na první pohled může navodit pocit odlišného vyznění toho, co je domov. Nejčastější jsou u obou stran totiž motivy žen a dětí - a v tom se obrázková korespondence znepřátelených mocností shoduje.

Začátek války vytvořil emoční propast mezi vojáky a jejich blízkými, kterou se miliony psaní, pohledů a zásilek pokoušely nějakým způsobem přemostit. V propagandě vidíme snahu dostat se $\mathrm{k}$ domovu skrz tyto vzkazy $\mathrm{z}$ fronty. Toto bylo jediné spojení dětí se svými otci, kteří se v dopisech svým ratolestem vyjadřovali v porovnání s velmi tvrdým životem válečníků až nezvykle jemně a něžně. Dopisy a pohlednice $z$ fronty a na frontu jsou místem vyjádření obav, lásky a osamění. Nasazení muži z nich působí ne tolik jako nezdolní hrdinové, ale právě jako citliví lidé, pro které byl domov, at už v jakékoli podobě, vším.

\section{SUMMARY}

\section{The Road Back - Depictions of Home on First World War postcards}

During World War I, over sixty-five million men were mobilized - they lost their home to gain a new one in the trenches, or on other places on the front. This article focuses on how the phenomena of home itself was depicted in the official poster and postcard propaganda. The goal of the essay is to identify and explain these depictions and attempt to find whether there was any crucial difference between how home was presented by the Central Powers and by the Entente, or if it was similar and how. The varying manner of depictions of home is described in the article along with the meanings of each of the pictured themes, set in the proper historical context. Some of the Central Powers' motives that stand out among the other are: home represented as the ruler, in this case as the emperors Franz Joseph I. or Wilhelm II., or home as the nation as a whole. On the Entente's side, the article observes a trend of presenting more worldly phenomena, such as home in the form of a village, a family, or supplies sent to the front. One of the depictions common to both the Entente and the Alliance is a vision, a pseudo-religious depiction of two places or actors in the same picture, for example the divided soldier and his wife. Various digital archives and auction houses' materials were used as the source of postcards and posters. By its end, the article arrives to the conclusion that even though the depictions of home certainly differ between the belligerent countries, on many posters - but most of all, on postcards - we see several identical themes. The reason for this is that these are themes that soldiers from all sides could have related to easily: pictures of wives, along with pictures of children. These were easy to imagine and helped convey the message placed on the poster or the postcard. 


\section{VÝBĚROVÁ BIBLIOGRAFIE}

George Macaulay Trevelyan, British History in the Nineteenth Century and after 1782-1919, City of Westminster 1979.

Rainer Traub - Christoph Gunkel, Propaganda-Postkarten im Ersten Weltkrieg: Singend in den Tod, Spiegel Online, https://www.spiegel.de/geschichte/bildpostkarten-im-ersten-weltkrieg-a-1026685 .html, vyhledáno 16. 1. 2021.

Roger Chickering, Imperial Germany and the Great War, 1914-1918, Cambridge 1998.

Staff Frank, The picture postcard \& its origins, Cambridge 1979.
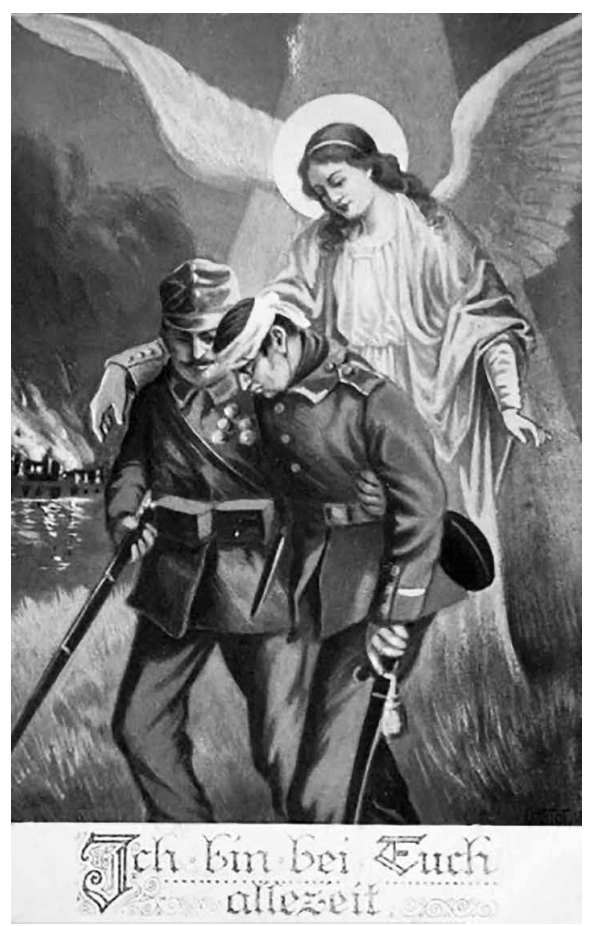

Obrázek 1. Autor neznámý, „Ich bin bei euch allezeit“, bez data. Reprodukce z knihy Ineke Veldhuis-Meester, The role of postcards in World War I; Historiana, https://historiana.eu/objects/7711237b-c609-423b -931 e-0ab14d09554c/The $\% 20$ role $\% 20$ of $\% 20$ Postcards\%20in\%20the\%20First\%20World\%20 War\%20_\%20Student\%20Material.pdf, vyhledáno 5. 2. 2021 

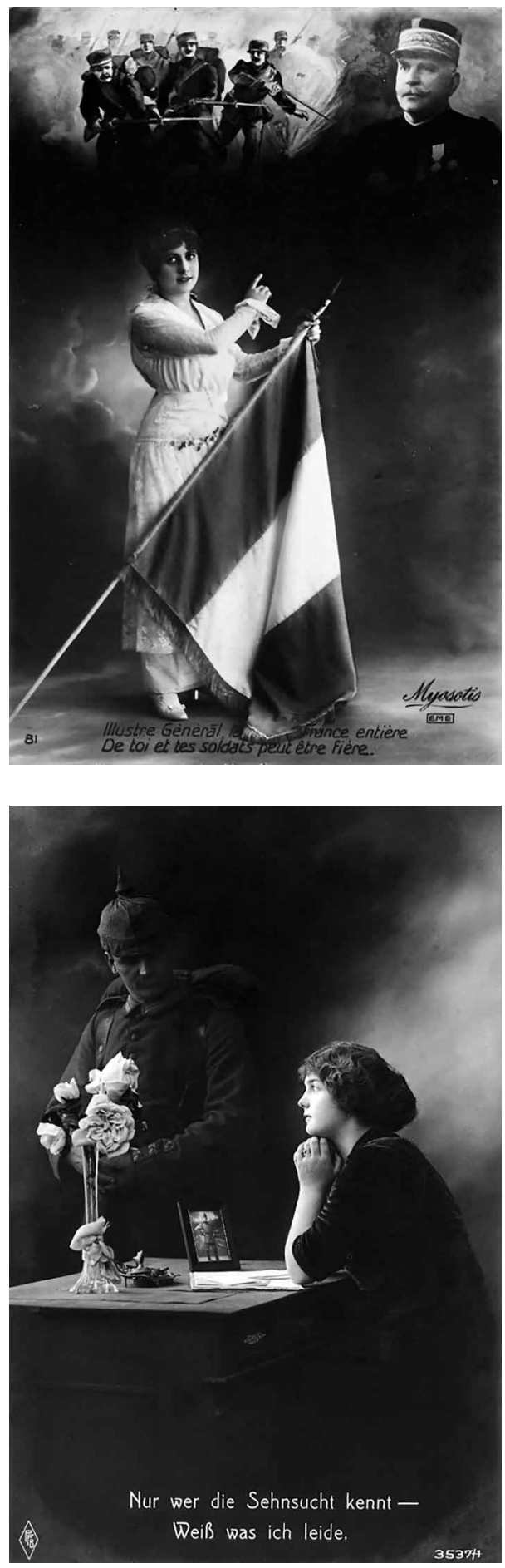

Obrázek 2. Autor neznámý, „Illustre General, la France entiére de toi et les soldats peut etre fiére", 1915. Reprodukce z knihy William A. Christian, Divine Presence in Spain and Western Europe 1500-1960, Budapest, b. d., s. 162-201
Obrázek 3. Autor neznámý, „Nur wer die sehnsucht kennt weiss was ich leide", 1916. Reprodukce z knihy William A. Christian, Divine Presence in Spain and Western Europe 1500-1960, Budapest, b. d., 162-201 


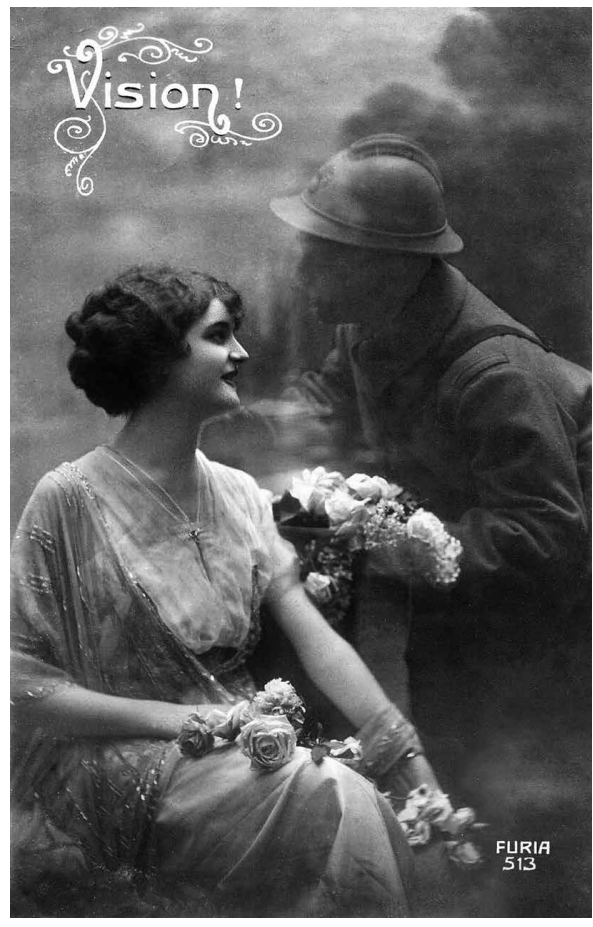

Obrázek 4. Autor neznámý, „Vision!“, 1916. Reprodukce z knihy William A. Christian, Divine Presence in Spain and Western Europe 1500-1960, Budapest, b. d., s. $162-201$ 